[5] Song 2012.

[6] Sieper 2013

[7] van Heijde 2014

[8] van Heijde 2016.

[9] Smolen 2017.

Disclosure of Interest: None declared

DOI: 10.1136/annrheumdis-2018-eular.4979

\section{SAT0270 LOW INCIDENCE OF BOTH NEW-ONSET AND FLARES OF UVEITIS IN SECUKINUMAB-TREATED PATIENTS WITH ANKYLOSING SPONDYLITIS: CLINICAL TRIAL AND POST-MARKETING SAFETY ANALYSIS}

A. Deodhar ${ }^{1}$, C. Miceli-Richard ${ }^{2}$, X. Baraliakos ${ }^{3}$, H. Marzo-Ortega ${ }^{4}$, D. D. Gladman ${ }^{5}$, R. Martin 6 , J. Safi Jr ${ }^{6}$, B. Porter ${ }^{6}$, A. Shete ${ }^{7} .{ }^{1}$ Oregon Health and Science University, Portland, USA; ${ }^{2}$ Hôpital Cochin, Paris, France; ${ }^{3}$ Rheumazentrum Ruhrgebiet, Herne, Germany; ${ }^{4}$ IHR LBRC, LTHT and LIRMM, University of Leeds, Leeds, UK; ${ }^{5}$ Toronto Western Hospital, Toronto, Canada; ${ }^{6}$ Novartis Pharmaceuticals Corporation, East Hanover, USA; ${ }^{7}$ Novartis Pharma AG, Basel, Switzerland

Background: Uveitis, a common extra-articular manifestation of SpA, has an estimated prevalence in patients (pts) with ankylosing spondylitis (AS) of $33.2 \%$, which increases with disease duration and positive HLA-B27 status. ${ }^{1}$ Uveitis occurs in $10 \%-50 \%$ of SpA pts. ${ }^{1}$ The exposure-adjusted incidence rate [EAIR] of uveitis (combined new-onset and flares) reported in AS pts treated with TNF inhibitors is 2.6-3.5 per 100 patient-years (pt-yrs). ${ }^{2-5}$

Objectives: To assess the incidence of uveitis in secukinumab-treated AS pts in long-term pooled clinical data from three phase 3 trials (MEASURE 1-3 [NCT01358175, NCT01649375, NCT02008916]) and from post-marketing analyses.

Methods: Analysis included pooled pt-level data from all pts in MEASURE 1 who received any dose $(\geq 1)$ of secukinumab up to the last pt attending Week 156 study visit, and up to visit Week 156 in MEASURE 2 and visit Week 104 in MEASURE 3 for each patient, respectively. Post-marketing data were from the most recent periodic safety surveillance report. Incidence of uveitis is reported as EAIR per 100 pt-yrs of secukinumab exposure.

Results: In the phase 3 AS clinical trials, 135 (17\%) pts reported pre-existing (but not active or ongoing) uveitis at baseline and $589(74.2 \%)$ pts were HLA-B27 positive. The EAIR for uveitis was 1.4 per 100 pt-yrs over the entire treatment period $(n=794)$. Among all cases of uveitis $(n=26), 14(54 \%)$ were flares in pts with a history of uveitis at baseline (Table). The EAIR of uveitis in the post-marketing data (based on cumulative secukinumab exposure of 96054 pt-yrs) was 0.03 per 100 pt-yrs.

Abstract SAT0270 - Table 1. Safety Analysis for Uveitis with Secukinumab in AS Data from Clinical Studies

Number of clinical studies/pts included

Uveitis cases reported, $\mathrm{n}(\%)$

Total

New onset cases

Treatment discontinuation

Treatment interruption

EAIR (95\% confidence interval) per 100 pt-yrs ${ }^{a}$

Post-Marketing Data ${ }^{\text {b }}$

Cumulative estimated market experience (pt-treatment yrs)

Cumulative number of cases reported

Crude incidence rate per 100 pt-yrs

${ }^{a}$ Rates are for uveitis MedDRA preferred term

${ }^{b}$ Data from the periodic safety update report (PSUR) dated 10th August 2017 includes all indications

${ }^{c}$ Estimated based on cumulative worldwide sales volume and the average maintenance dose

Conclusions:

In secukinumab-treated pts with active AS, a low incidence of uveitis was observed, including new-onset cases and flares, in both clinical trials and postmarketing analyses.

REFERENCES:

[1] Zeboulon, et al. Ann Rheum Dis 2008;67:955-59.

[2] Wendling, et al. Curr Med Res Opin 2014;30:2515-21.

[3] Van der Heijde, et al. Rheumatology (Oxford) 2017;56:1498-509.

[4] Sieper, et al. Arthritis Rheum 2014;66:S242.

[5] Heldmann, et al. Clin Exp Rheumatol 2011;29:672-80.
Disclosure of Interest: A. Deodhar Grant/research support from: AbbVie Inc., Eli Lilly, GSK, Janssen, Novartis, Pfizer Inc., UCB, Consultant for: AbbVie, Eli Lilly, Janssen, Novartis, Pfizer, UCB, C. Miceli-Richard Grant/research support from: Pfizer, Roche, UCB, Wyeth, Merck, Consultant for: Abbott/AbbVie, BristolMyers Squibb, Novartis, Merck, Pfizer, Wyeth, Speakers bureau: Abbott, BristolMyers Squibb, Merck, Pfizer, Roche, Schering-Plough, Wyeth., X. Baraliakos Grant/research support from: AbbVie, BMS, Celgene, Chugai, MSD, Novartis Pfizer, UCB, Consultant for: AbbVie, BMS, Celgene, Chugai, MSD, Novartis, Pfizer, UCB, Speakers bureau: AbbVie, BMS, Celgene, Chugai, MSD, Novartis, Pfizer, UCB, H. Marzo-Ortega Grant/research support from: Janssen and Pfizer, Consultant for: AbbVie, Celgene, Janssen, Novartis and UCB, Speakers bureau: AbbVie, Celgene, Janssen and UCB, D. Gladman Grant/research support from: Amgen, AbbVie, BMS, Celgene, Eli Lilly, Janssen, Novartis, Pfizer and UCB., Consultant for: Amgen, AbbVie, BMS, Celgene, Eli Lilly, Janssen, Novartis, Pfizer and UCB., R. Martin Shareholder of: Novartis, Employee of: Novartis, J. Safi Jr Shareholder of: Novartis, Employee of: Novartis, B. Porter Shareholder of: Novartis, Employee of: Novartis, A. Shete Shareholder of: Novartis, Employee of: Novartis

DOI: 10.1136/annrheumdis-2018-eular.4474

\section{SAT0271 SECUKINUMAB, A FULLY HUMAN ANTI-INTERLEUKIN- 17A MONOCLONAL ANTIBODY, EXHIBITS LOW IMMUNOGENICITY IN PATIENTS WITH PSORIATIC ARTHRITIS AND ANKYLOSING SPONDYLITIS DURING A 52-WEEK TREATMENT PERIOD}

A. Deodharr', D. Gladman ${ }^{2}$, I. McInnes ${ }^{3}$, M. Ren ${ }^{4}$, S. Spindeldreher ${ }^{5}$, L. Pricop ${ }^{6}$, B. Porter ${ }^{6}$, J. Safi ${ }^{6}$, A. Shete ${ }^{7}$, G. Bruin ${ }^{5} .{ }^{1}$ Oregon Health and Science University, Portland, USA; ${ }^{2}$ Toronto Western Hospital, Toronto, Canada; ${ }^{3}$ University of Glasgow, Glasgow, UK; ${ }^{4}$ Novartis Pharmaceuticals, Shanghai, China: ${ }^{5}$ Novartis Institutes for Biomedical Research, Basel, Switzerland; ${ }^{6}$ Novartis Pharmaceuticals Corporation, East Hanover, USA; ${ }^{7}$ Novartis Pharma AG, Basel, Switzerland

Background: Secukinumab (SEC), a fully human monoclonal antibody (mAb) that selectively targets IL-17A, is highly efficacious for the treatment of psoriatic arthritis (PsA) and ankylosing spondylitis (AS). mAb therapies may be associated with immunogenicity (IG) and production of anti-drug antibodies (ADAs) that may cause adverse events (AEs), and affect drug pharmacokinetics (PK) and clinical response.

\begin{tabular}{|c|c|c|c|c|c|c|c|}
\hline \multirow[t]{6}{*}{$\begin{array}{l}\text { PsA } \\
\text { studies }\end{array}$} & Study & $\begin{array}{l}\text { SEC } \\
\text { dose }\end{array}$ & $\begin{array}{c}\text { Prior } \\
\text { biologics }\end{array}$ & $\begin{array}{c}\text { ADA } \\
\text { (titer)/ } \\
\text { Neut-Ab }\end{array}$ & $\begin{array}{l}\mathrm{AE} \mathrm{IG} \\
\text { related }\end{array}$ & $\begin{array}{l}\text { Impact on } \\
\text { efficacy }^{2}\end{array}$ & $\begin{array}{c}\text { PK } \\
\text { behaviour }\end{array}$ \\
\hline & F2306 & $\begin{array}{c}\text { PBO-75 } \\
\text { mg }\end{array}$ & 0 & $\begin{array}{c}\text { W24 (no } \\
\text { titer)/Y }\end{array}$ & $\mathrm{N}$ & None & Normal \\
\hline & $\bar{F} 2312$ & $\begin{array}{c}\text { PBO-150 } \\
\text { mg }\end{array}$ & 0 & $\begin{array}{c}\text { W52 } \\
(2.99) / \mathrm{N}\end{array}$ & $\mathrm{N}$ & None & Normal \\
\hline & $\bar{F} 2318$ & $150 \mathrm{mg}$ & Infliximab & $\begin{array}{c}\text { W52 } \\
(2.14) / N\end{array}$ & $\mathrm{~N}$ & None & Normal \\
\hline & & $150 \mathrm{mg}$ & 0 & $\begin{array}{c}\text { W24 } \\
(1.00) / \mathrm{N}\end{array}$ & $\mathrm{N}$ & None & Normal \\
\hline & & $150 \mathrm{mg}$ & 0 & $\begin{array}{c}\text { W52 } \\
(2.59) / \mathrm{N}\end{array}$ & $\mathrm{N}$ & None & Normal \\
\hline \multirow[t]{8}{*}{$\begin{array}{l}\text { AS } \\
\text { studies }\end{array}$} & F2305 & $\begin{array}{c}10 \mathrm{mg} / \\
\mathrm{kg}- \\
150 \mathrm{mg}\end{array}$ & 0 & $\begin{array}{c}\text { W52 } \\
(2.39) / \mathrm{N}\end{array}$ & $\mathrm{N}$ & None & Normal \\
\hline & & $\begin{array}{c}\text { PBO-150 } \\
\text { mg }\end{array}$ & 0 & $\begin{array}{c}\text { W52 } \\
(10.61) / N\end{array}$ & $\mathrm{~N}$ & None & Normal \\
\hline & F2310 & $\begin{array}{c}\text { PBO-75 } \\
\text { mg }\end{array}$ & 0 & $\begin{array}{c}\text { W52 } \\
(39.39) / \mathrm{N}\end{array}$ & $\mathrm{N}$ & None & Normal \\
\hline & $\mathrm{F} 2314$ & $\begin{array}{c}\text { PBO-300 } \\
\text { mg }\end{array}$ & 0 & $\begin{array}{c}\text { W52 } \\
(1.02) / \mathrm{N}\end{array}$ & $\mathrm{N}$ & None & Normal \\
\hline & F2320 & $150 \mathrm{mg}$ & 0 & $\begin{array}{c}\text { W16 } \\
(6.35) / \mathrm{N} \\
\text { W52/ } \\
(2.96) / \mathrm{N}\end{array}$ & $\mathrm{N}$ & $\begin{array}{l}\text { None } \\
\text { None }\end{array}$ & Normal \\
\hline & & $\begin{array}{l}150 \mathrm{mg} \\
\text { No Load }\end{array}$ & 0 & $\begin{array}{c}\text { W16 } \\
(2.70) / \mathrm{N}\end{array}$ & $\mathrm{N}$ & None & Normal \\
\hline & & 150 mg & 0 & $\begin{array}{c}\text { W24/ } \\
(2.80) / \mathrm{N}\end{array}$ & $\mathrm{N}$ & None & Normal \\
\hline & & $\begin{array}{l}\text { PBO- } \\
150 \mathrm{mg}\end{array}$ & 0 & $\begin{array}{c}\text { W52/ } \\
(2.89) / \mathrm{N}\end{array}$ & $\mathrm{N}$ & None & Normal \\
\hline
\end{tabular}


Neut-Ab=neutralising antibodies; PBO, placebo; $\mathrm{Y}$, yes; $\mathrm{N}$, No. ${ }^{1}$ Only positive ADA results at the respective study week are shown; ${ }^{2}$ Impact on efficacy is defined as: PsA, failure to achieve $>20 \%$ reduction, compared to baseline, in both tender and swollen joint counts; AS, failure to achieve ASAS20, after previously achieving such improvement for at least 2 consecutive visits prior to the first detection of ADA; ${ }^{3}$ Normal PK: Concentrations in ADA-positive pts within observed range for all pts without $A D A$

Objectives: To assess the IG of SEC in PsA and AS patients (pts) treated with SEC for up to 52 weeks (W).

Methods: IG in pts with PsA (FUTURE 1-3 studies, $n=1414$ ) and AS (MEASURE 1-4 studies, $n=1163$ ) exposed to SEC was evaluated at baseline (BL) and at $W$ 12, 16 (AS only), 24 and 52. Treatment emergent (TE)-ADA were defined as a positive ADA signal in $\geq 1$ post-treatment sample in pts negative at BL. TE-ADA positive samples were analysed for drug-neutralising potential, SEC impact on PK, IG-related AEs and TE-ADA impact on efficacy through W52.

Results: Of 1414 treated PsA and 1163 treated AS pts with samples for IG evaluation, $5(0.35 \%)$ and $8(0.68 \%)$ developed TE-ADAs respectively, over 52 weeks (Table). All but 1 PsA pt were biologic naïve; $2 / 5$ PsA and $1 / 8$ AS pts received concomitant methotrexate, 2/8 AS pts received concomitant sulfasalazine. Associations between TE-ADAs and SEC dose, frequency or mode of administration were not observed. Other than 1 PsA pt, all TE-ADAs were non-neutralising and none were associated with any IG-related AE. All TE-ADAs were associated with normal PK and none were associated with loss of SEC efficacy over 52 weeks. Conclusions: SEC treatment was associated with a low incidence of IG in PSA and AS pts, as shown by TE-ADA detection in only $0.35 \%$ PsA pts and $0.68 \%$ AS pts over 52 weeks in a database of $>2500$ pts, which is consistent with the low incidence of IG $(0.4 \%)$ seen with SEC in pts with plaque psoriasis.

\section{REFERENCE:}

[1] Reich K, et al. Br J Dermatol 2017;176:752.

Disclosure of Interest: A. Deodhar Grant/research support from: AbbVie, Amgen, Eli Lilly, GSK, Janssen, Novartis, Pfizer and UCB, Consultant for: Eli Lilly, Janssen, Novartis, Pfizer and UCB, D. Gladman Grant/research support from: Amgen, AbbVie, BMS, Celgene, Eli Lilly, Janssen, Novartis, Pfizer and UCB, I. Mclnnes Grant/research support from: AbbVie, Amgen, BMS, Celgene, Janssen, Lilly, Novartis, Pfizer and UCB, Consultant for: AbbVie, Amgen, BMS, Celgene, Janssen, Lilly, Novartis, Pfizer and UCB, Speakers bureau: AbbVie, Amgen, BMS, Celgene, Janssen, Lilly, Novartis, Pfizer and UCB, M. Ren Employee of: Novartis, S. Spindeldreher Shareholder of: Novartis, Employee of: Novartis, L. Pricop Shareholder of: Novartis, Employee of: Novartis, B. Porter Shareholder of: Novartis, Employee of: Novartis, J. Safi Shareholder of: Novartis, Employee of: Novartis, A. Shete Shareholder of: Novartis, Employee of: Novartis, G. Bruin Shareholder of: Novartis, Employee of: Novartis DOI: 10.1136/annrheumdis-2018-eular.3646

\section{SAT0272 \\ DO TNF INHIBITORS IMPACT THE COMORBIDITIES AND EXTRA-ARTICULAR MANIFESTATIONS, AND THEREBY ALTER THE NATURAL HISTORY OF ANKYLOSING SPONDYLITIS?}

A. Deodhar ${ }^{1}$, K.L. Winthrop ${ }^{1}$, R.L. Bohn ${ }^{2}$, B.K. Chan ${ }^{1}$, R.Y. Suruki ${ }^{2}$, J.L. Stark ${ }^{3}$, H. Yun ${ }^{4}$, S.A.R. Siegel ${ }^{1}$, L. Chen ${ }^{4}$, M. Yassine ${ }^{3}$, J.R. Curtis ${ }^{4}{ }^{1}{ }^{\text {Oregon Health and }}$ Science University, Portland, OR; ${ }^{2}$ UCB Pharma, Raleigh, NC; ${ }^{3}$ UCB Pharma, Smyrna, GA; ${ }^{4}$ University of Alabama at Birmingham, Birmingham, AL, USA

Background: Anti-tumour necrosis factor (anti-TNF) treatment has led to reduction in signs and symptoms, and improvements in physical function and quality of life in ankylosing spondylitis (AS) patients (pts). Whether anti-TNFs impact the incidence of AS-related comorbidities and extra-articular manifestations (EAMs) is not known.

Objectives: To evaluate the incidence and prevalence of AS-related comorbidities and EAMs in AS pts in the US.

Methods: This was a retrospective cohort study of 3 commercial insurance claims databases (Multi-Payer Claims Database [MPCD 2007-2010], Truven MarketScan [2010-2014], and US Medicare Fee-for-Service Claims [20062014]) to evaluate EAMs (uveitis, psoriasis, inflammatory bowel disease) and physician-diagnosed comorbidities (cardiac, renal, pulmonary, neurologic) in AS pts diagnosed by a rheumatologist (index date), having 6 months' baseline data prior to the index date, and drug-specific exposures after AS diagnosis (ICD-9 720.0). Three mutually exclusive hierarchical exposure groups were examined (low to high): ${ }^{1}$ no therapy or prescription NSAIDs, ${ }^{2}$ conventional DMARDs; ${ }^{3}$ anti-
TNFs. Prevalence of comorbidities was ascertained in a 12 month period (6 months pre- and post-index date). Incidence of comorbidities and EAMs was assessed during the period between treatment initiation and the earliest of death loss of medical coverage, end of study, first outcome occurrence, treatment discontinuation or initiation of therapy at a higher level in exposure hierarchy. Pts with a history of prior events (except infections) were excluded from the incidence assessment for that event. Hazard ratios comparing anti-TNFs vs DMARDs and NSAIDs/no therapy were estimated using inverse probability treatment weighted Cox proportional hazards models.

Results: A total of 37,566 AS pts were included. Prevalence of AS in the MPCD population was $0.26 \%$ and in the Medicare population was $1.21 \%$. As expected comorbidities were more common in Medicare AS pts vs those in MPCD or MarketScan databases in all exposure groups. The propensity score-weighted incidences of solid cancers, myocardial infarction, conduction block, cord compression and vertebral fractures were lower in anti-TNF treated pts vs those treated with NSAIDs or DMARDs alone, although anti-TNF treated Medicare pts had a higher incidence of EAMs such as psoriatic arthritis, uveitis and ulcerative colitis (figure 1)

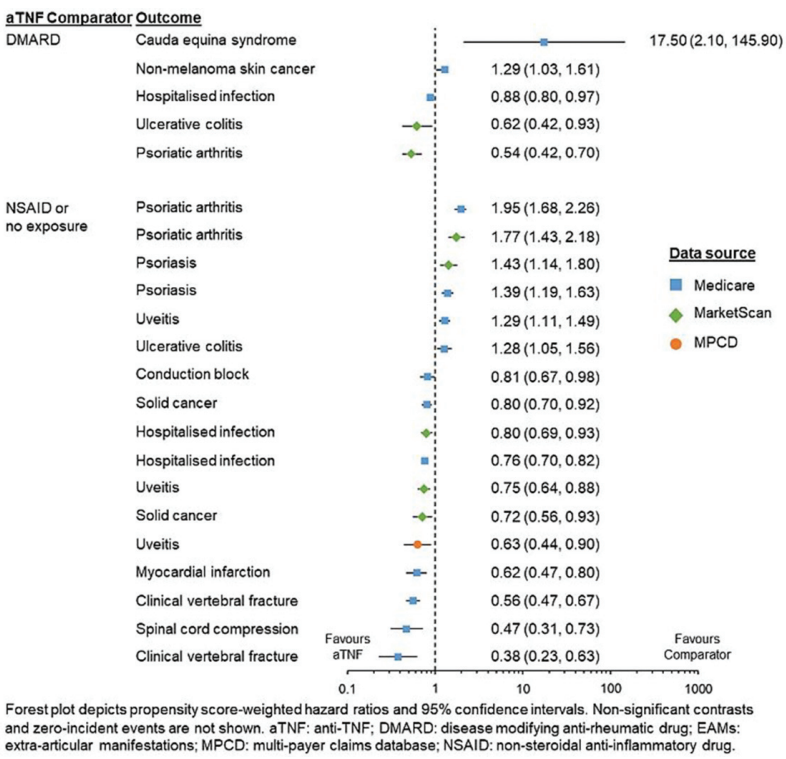

Abstract SAT0272 - Figure 1. Propensity score-weighted hazard ratios of physiciandiagnosed outcomes and EAMs by treatment exposures

Conclusions: This investigation of the prevalence and incidence of comorbidities and EAMs of AS in US pts suggests that anti-TNF use is associated with a lower incidence of some comorbidities, and a trend of higher incidence of EAMs, which may reflect channelling of more severe AS pts to anti-TNFs. Although results vary somewhat by data source and may be explained by different baseline characteristics (e.g. Medicare pts were older), our results suggest that anti-TNF use is associated with lower incidence of those comorbidities that confer substantial morbidity in AS.

Acknowledgements: This study was undertaken in conjunction with UCB Pharma. Editorial services were provided by Costello Medical.

Disclosure of Interest: A. Deodhar Grant/research support from: Amgen, El Lilly, GSK, Janssen, Novartis, UCB Pharma, Speakers bureau: Eli Lilly, Janssen, Novartis, UCB Pharma, K. Winthrop Grant/research support from: BMS, Consultant for: AbbVie, BMS, Galapagos, GSK, Eli Lilly, Pfizer, Roche, UCB Pharma, R Bohn Employee of: Bohn Epidemiology, LLC and UCB Pharma, B. Chan: None declared, R. Suruki Employee of: UCB Pharma, J. Stark Employee of: UCB Pharma, H. Yun Grant/research support from: BMS, S. Siegel: None declared, L. Chen: None declared, M. Yassine Employee of: UCB Pharma, J. Curtis Grant/ research support from: Amgen, BMS, Janssen, Eli Lilly, Myriad Genetics, Novartis, Pfizer, Roche, UCB Pharma, Consultant for: Amgen, BMS, Janssen, Eli Lilly, Myriad Genetics, Novartis, Pfizer, Roche, UCB Pharma DOI: 10.1136/annrheumdis-2018-eular.2890 